\title{
Homing of Mesenchymal Stem Cells
}

\author{
Reinhard Henschler Erika Deak Erhard Seifried \\ Institute of Transfusion Medicine and Immune Hematology, German Red Cross Blood Donor Center, \\ Johann Wolfgang Goethe-University Frankfurt, Germany
}

\section{Key Words}

Mesenchymal stem cells · MSC · Homing ·

Mesenchymal stromal cells

\section{Summary}

Mesenchymal stem cells (MSCs) are primarily fibroblast-like cells. Yet, once studied under conditions of shear stress when flowing along endothelial cells in vitro or in blood vessels, as well as in classic migration assays such as chemotaxis assays, MSCs have recently been found to function similarly to leukocytes in many ways. Firstly, MSCs express several homing receptors which are typically activated during extravasation of leukocytes. Secondly, some of these receptors are definitely functional, and required for their tissue localization in certain physiological or pathological contexts. Clinical protocols have in the last few years provided the first data on whether and how human MSCs may work in patients once delivered locally e.g. by injection, or systemically via the intra-arterial or intravenous route. Still, analysis of the ability of MSCs to activate specific homing receptors has up to now received relatively little attention. Moreover, maintenance or alterations of homing receptor expression or functions during good manufacturing practice (GMP) preparation steps, and documentation of presence and function of individual pathways on MSC preparations for clinical use are often missed. Hence, we review here mechanisms predicted to be relevant for adhesion, migration, and homing competence of MSCs. We also discuss some early data on homing of MSCs, deduced from preclinical experiments and from the few clinical studies with MSCs. Finally, we introduce some assays which could be applied to monitor preservation of the homing capacity of MSCs during GMP preparation.

\author{
Schlüsselwörter \\ Mesenchymale Stammzellen · MSC · Homing · \\ Mesenchymale Stromazellen
}

\section{Zusammenfassung}

Mesenchymale Stammzellen (MSCs) sind primär fibroblastenartige Zellen. Die Untersuchung von MSCs unter Bedingungen mit Scherdruck beim Durchlaufen endothelialer Zellen in vitro bzw. in Blutgefäßen, sowie in klassischen Migrationsassays (z.B. Chemotaxis-Assays) ergab, dass MSCs in vielerlei Hinsicht ähnliche Funktionen wie Leukozyten zeigen. Erstens exprimieren MSCs mehrere Homing-Rezeptoren, die typischerweise bei Extravasation von Leukozyten aktiviert werden. Zweitens sind einige dieser Rezeptoren definitiv funktionstüchtig und notwendig für die Gewebelokalisation von MSCs in bestimmten physiologischen oder pathologischen Situationen. Klinische Protokolle haben in den letzten Jahren erste Daten dazu geliefert, ob und wie humane MSCs funktionieren, nachdem sie lokal (z.B. durch Injektion) oder systemisch (intraarteriell bzw. intravenös) an Patienten verabreicht worden sind. Dennoch ist der Analyse der Fähigkeit von MSCs, spezifische Homing-Rezeptoren zu aktivieren, bisher nur wenig Aufmerksamkeit geschenkt worden. Außerdem werden die Aufrechterhaltung bzw. Veränderungen der Homing-Rezeptorexpression und -funktion während der GMP(good manufacturing practice)-Herstellungsschritte sowie die Dokumentation der Anwesenheit und Funktion einzelner Signalwege in MSC-Präparaten für die klinische Nutzung oft wenig beachtet. Wir geben deshalb einen Überblick über die Mechanismen, von denen angenommen wird, dass sie für die Adhäsion, Migration und Homing-Kompetenz von MSCs relevant sind. Außerdem diskutieren wir einige Daten zum Homing-Verhalten von MSCs, die von präklinischen Experimenten und den wenigen klinischen Studien mit MSCs stammen, und stellen einige Methoden vor, die zur Überwachung der Erhaltung der Homing-Kapazität von MSCs während der GMP-Herstellung geeignet sein könnten.

\begin{tabular}{ll}
\hline KARGER & $\oplus$ 2008 S. Karger GmbH, Freiburg \\
Fax +497614520714 & Accessible online at: \\
$\begin{array}{l}\text { E-mail Information@Karger.de } \\
\text { www.karger.com }\end{array}$ & www.karger.com/tmh
\end{tabular}

Dr. med. Reinhard Henschler

Institute of Transfusion Medicine and Immune Hematology,

German Red Cross Blood Donor Center

Johann Wolfgang Goethe-University Frankfurt

Sandhofstraße 1, 60528 Frankfurt, Germany

Tel. +49 69 6782-191, Fax -258, r.henschler@blutspende.de 


\section{Homing Functions of Stem Cells, Especially of Mesenchymal Stem Cells}

Mostly in the 1990s, a bunch of different classes of adhesion receptors was discovered on leukocytes and their ligands on endothelial cells. The regulation of their expression and of their functioning under conditions of shear flow both in vitro and in vivo have been described. The main classes of relevant receptors which have been antigenically defined, cloned, and expressed, and in several cases knocked out in murine gene deletion models are i) selectins (mostly on endothelial cells) which recognize either lectin ligands such as P-selectin glycoprotein ligand-1 (PSGL-1) or other receptors such as the CD44 molecule on leukocytes; ii) integrins on leukocytes and, as ligands on the endothelial/stromal cell side, vascular cell adhesion molecule-1 (VCAM-1), intercellular adhesion molecule-1 (ICAM-1) and ICAM-2, fibronectin, vitronectin; iii) chemokines and their receptors including both $\mathrm{CC}$ and $\mathrm{CXC}$ chemokines and their respective receptors [1]. Here, the most intensively studied receptor/ligand pair is the CXCR4 receptor on leukocytes and its ligand CXCL12/stromal derived factor-1 (SDF-1) on endothelial cells or stromal cells [1,2]. The main functions of the different classes of receptors have been delineated by the pioneering work mainly by the Butcher and Springer groups, termed 'multistep model of leukocyte extravasation' $[1,3,4]$. This includes i) as a first step of leukocyte-endothelial interactions, tethering (initial contact) and rolling interactions (deceleration from the blood flow in the target vessels, e.g. high endothelial venules or sinuses of the bone marrow) by selectin/lectin interactions; ii) induction of 'sudden arrest' of rolling leukocytes by sub-second activation of chemokine/ chemokine receptor pairing which, within milliseconds, activates integrins to alter their confirmation in order to induce firm adhesion of previously rolling cells [5, 6]. Subsequently, further enhancement of integrin binding avidity is necessary, a process termed 'adhesion strengthening', which is again enforced through chemokine receptor interaction and integrin avidity regulation, and which involves $\mathrm{G}$ protein-mediated intracellular signaling [7]. Cells will polarize during these adhesion upregulation steps, and receive further cues which direct transendothelial migration by other receptors such as CD31, CD99, or junctional adhesion molecules (JAMs) [8].

In hematopoietic stem and progenitor cells, these molecules have, in a very similar way as in leukocytes, been found responsible for mediating egress of transplanted stem cells to their target tissues - mostly, to hematopoietic tissue such as bone marrow and spleen [9]. However, although the participation of many of these molecules in a coordinated homing process has been recognized and secured also in the case of hematopoietic stem and progenitor cells, it has up to now been less clear which molecules provide the local information as to where a circulating stem cell will emigrate from the bloodstream. A recent study using two-photon emission microscopy showed localized presentation of E-selectin and SDF-1 in sinusoidal venules in skull bone of the mouse, whereas other adhesion ligands present on the stromal side such as VCAM-1 were found continuously expressed [10]. This indicates that VCAM-1, although a necessary components of stem and progenitor cell homing, would not determine site specificity of egress and thus homing, whereas E-selectin and SDF-1 locally expressed on the luminal side of endothelial cells may confer site specificity [10].

In the case of mesenchymal stem cells (MSCs), the expression of homing receptors such as the ones previously shown to be relevant for homing of hematopoietic stem and progenitor cells has been relatively well investigated and characterized. Still, many questions are unresolved as to the function of these receptors in MSCs. MSCs have been shown to roll on P-selectin present on endothelial cells or in postcapillary venules [11]. Yet, the expected ligands for P-selectin, PSGL-1 or the CD24 molecule, were not found expressed in human MSCs [11]. However, MSCs express CD44, a putative ligand for Eselectin. Sackstein et al. [12] have revealed that enzymatically fucosylated CD44 on MSCs renders them capable of binding to E-selectin. Whereas L-selectin, which is an important receptor for neutrophil, lymphocyte, or monocyte extravasation to target sites, was not found expressed, or transcribed in only minor amounts in human MSCs (hMSCs), indicating that this typically leukocyte-expressed receptor may not be functioning in MSCs [11].

In contrast to the relatively complex situation with selectin/ligand interactions, hMSCs have been shown to express a high number of integrin receptors, including integrins alpha1, alpha2, alpha3, alpha5, alpha6, alphav, beta1, beta3, and beta4, making them capable of forming alpha/beta dimers which have been found relevant for hematopoietic stem cell homing, such as alpha4beta1 (VLA-4) and alpha5beta1 (VLA-5) [13, 14]. Yet, beta2 integrins, the expected ligands conferring MSC binding to ICAM-1 and -2, were not found expressed [14]. Evidence that MSCs use integrins in shear resistant binding to endothelial cells comes from studies in a myocardial infarct model demonstrating that MSC binding to VCAM-1 is required for their extravasation [15], and from studies in parallel plate flow chambers indicating that VCAM1/VLA4 is a necessary but not sufficient component for arrest of MSCs to endothelial cells [11].

Avidity of integrins is typically regulated by chemokines. A number of studies have so far investigated expression of chemokine receptors on MSCs. These include CCR1, CCR7, CCR9, CXCR4, CXCR5, CXCR6, and CX3CR1 [16, 17]. Functionality of CXCR4 has been demonstrated in at least a subpopulation of hMSCs using a transwell migration assay [18]. Shi et al. [19] demonstrated that flk1+ fetal-derived hMSCs can express CXCR4 which is usually intracellular and can be brought to the cell surface by cytokine pre-incubation, resulting in functional receptor. In vivo function of CXCR4 has been demonstrated e.g. in a brain infarct rat model where 
Table 1. Molecules which have been shown to affect homing behavior of MSCs in preclinical model systems

\begin{tabular}{lll}
\hline Study [Ref.] & Receptor & Result \\
\hline Sackstein [12] & CD44/HCAM on hMSCs & $\begin{array}{l}\text { fucosylation and sulfation before transplant restores } \\
\text { ability of MSCs to home to bone marrow/bone }\end{array}$ \\
\hline Herrera [49] & CD44 on mMSCs & $\begin{array}{l}\text { improved recovery from acute renal failure only with } \\
\text { CD44+ MSCs }\end{array}$ \\
\hline Rüster et al. [11] & $\begin{array}{l}\text { yet unknown, fucosylated and sialylated } \\
\text { P-selectin ligand on MSCs and endothelial } \\
\end{array}$ & $\begin{array}{l}\text { P-selectin } \\
\text { rolling on endothelial cells under shear stress } \\
\text { requires P-selectin in vitro and in vivo }\end{array}$ \\
\hline Segers et al. [15] & $\begin{array}{l}\text { VCAM-1 on cardiac microvascular } \\
\text { endothelial cells }\end{array}$ & $\begin{array}{l}\text { transmigration across endothelial cells in myocardial } \\
\text { ischemia depends on flow rate and functional VCAM-1 }\end{array}$ \\
\hline Shi et al. [19] & $\begin{array}{l}\text { CXCR4 upregulation by cytokine pre- } \\
\text { treatment }\end{array}$ & $\begin{array}{l}\text { increased engraftment of co-transplanted hHSCs } \\
\text { Hung [50] }\end{array}$ \\
$\begin{array}{lll}\text { hypoxia increases CXCR4 and CX3CR1 } \\
\text { expression }\end{array}$ & $\begin{array}{l}\text { increased MSC transmigration to chemokines, and } \\
\text { increased engraftment in chick embryo assay }\end{array}$ \\
\hline
\end{tabular}

Fig. 1. Representation of the multistep interaction model during leukocyte recruitment as proposed by Springer et al. [4]. Molecules shown to be relevant in MSC homing are underlined and in bold font.

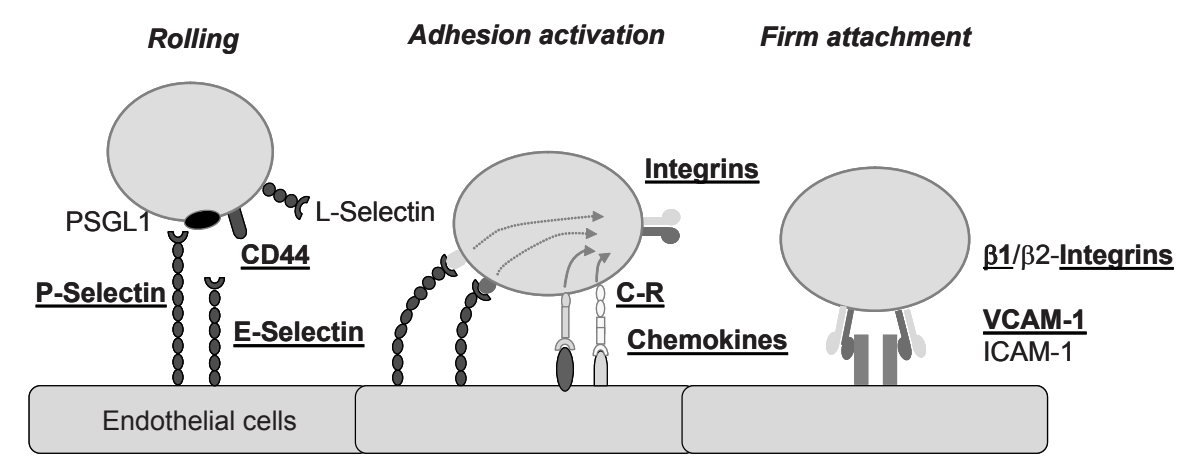

intracerebral injection of SDF-1alpha has been shown to stimulate homing of transplanted MSCs to the site of injection. Similarly, in a hypoglossal nerve injury system, local expression of SDF-1 and also fractalkine correlated with immigration and repair function of MSCs transplanted into the lateral ventricles [20]. Using a transwell chemotaxis assay, other chemokines which can stimulate migration of MSCs are MCP1, MIP-1, and IL-8 [21].

Further steps in emigration from blood vessels cover their transgress through endothelium, crossing of the basement membrane, then intra-tissue migration following likely chemotactic gradients, and lastly, maintenance in a final destination ('niche'). Limited data exist on the ability of culture-derived MSCs to follow the individual steps. Yet, MSCs have been shown to be capable of activation matrix metalloproteinases to promote their intra-tissue egress and migration [22]. A short summary of homing receptors which have been shown to play a role in MSC homing (or at least site specific engraftment) is given in table 1 . An outline of the multi-step model of leukocyte recruitment and its relevance to homing steps in MSCs is shown in figure 1.

\section{Techniques Available to Follow Homing and Tissue Distribution of Mesenchymal Stem Cells}

\section{RT-PCR, with or without Reporter Genes}

Genomic reverse transcription polymerase chain reaction (RT-PCR) is likely to be the most straightforward and simple means to trace MSCs. Either a transduced transgene, or individual donor markers can be used for this purpose, and transplanted MSC-specific signals have been obtained in several patient studies, where e.g. bone marrow specimens provide enough material to follow the fate of MSCs [23-25]. The results are generally semi-quantitative.

\section{Labeling Techniques}

An alternative, allowing non-invasive tracing of transplanted MSCs, is radiolabeling using e.g. ${ }^{111}$ In-oxime, a derivative of an indium isotope with a half-life of approximately $67 \mathrm{~h}$. So far, this has been used in non-human primates and dogs, and allowed to successfully trace transplanted MSCs. With this technique, the tissue distribution of transplanted MSCs was followed over a period of $48 \mathrm{~h}$ using a gamma camera in a rat 
myocardial infarct model [26]. Alternatively, or in addition, superparamagnetic iron oxide particles (SPIO) have been used with success in this context in various preclinical large animal models. The procedure involves a take-up procedure that is principally amenable to good manufacturing practice (GMP) procedures, especially since the used contrast agent, Feridex ${ }^{\mathrm{TM}}$ (Bayer Health Care Pharmaceuticals, Leverkusen, Germany), is approved for human (diagnostic) use [27]. Labeling can be reached using classical transfection reagents also amenable to GMP [28]. In leukocyte trafficking studies, this technique has been used to identify the kinetics of inflammatory leukocyte invasion after human myocardial infarction to be 24-96 h, suggesting that this process was dependent on a specific tissue uptake mechanism of the leukocytes [29].

Recently, Kraitchman et al. [30] have used double labeling of MSCs with ${ }^{111}$ In-oxine and SPIO in a dog myocardial infarction model, and analyzed the fate of approximately $5 \times 10^{6} / \mathrm{kg}$ i.v. injected MSCs using combined single-photon emission computed tomography (SPECT) and X-ray CT (SPECT/ CT), as well as magnetic resonance imaging (MRI). They showed that MSCs undergo several typical steps after intravenous (i.v.) administration: i) biphasic distribution with early accumulation in the lungs, and later major accumulation in liver and kidney; ii) slow but continuous clearance form all organs over a period of 7-10 days; and iii) focal accumulation of MSC-derived signals on day 1 after MSC application in infarcted myocardium. They found high agreement between quantitative SPECT imaging and tissue gamma well counting, and confirmed in post mortem analyses that MSCs had arrived in rim zones of the infarct using tissue sections stained with the iron-staining Prussian blue technique. In contrast, MRI was not useful in tracing transplanted MSCs, due to its lower sensitivity.

\section{Evidence for a Coordinated Migration and Circulation Behavior of Mesenchymal Stem Cells}

\section{A Role of the Lungs in Early Phases of MSC Engraftment}

As described above, the possibility remains that MSCs are non-specifically trapped in the lung early after transplantation. Murine MSCs (mMSCs) have been found to accumulate in lungs and to be retained locally, resulting in long-term pathological alterations [31]. This seems not, or to a low degree only, to be the case with hMSCs where after transplantation into NOD/SCID mice, loss of the PCR signal has been documented. This suggests that hMSCs may be initially trapped, but are eventually cleared from the lungs. Gao et al. [26] have however made likely a role of lung trapping of freshly transplanted MSCs for their further circulation and tissue homing behavior: They found that ${ }^{111}$ In-labeled MSCs accumulate to a far lesser degree in lungs and are seen earlier and to a higher degree in other tissues if a lung vasodilator was applied preceding the MSC transfusion in a rat model.

\section{Distribution of Transplanted MSCs to Other Tissues}

In baboons, Devine et al. [32] have used quantitative RT-PCR to trace distribution of transplanted MSCs for a period of up to 1 year. They found that many tissues including kidney, lung, liver, thymus, and skin were also found to contain relatively high amounts of DNA equivalents. Among these, gastrointestinal tissues harbored the relatively highest concentrations of transgene per microgram of DNA. The estimated engraftment levels using this technique were however quite high, ranging from 0.1 to $2.7 \%$, seemingly in some discordance to the histopathological findings from tissue sections, which remains difficult to explain. So far, clear post mortem data from humans receiving MSCs are lacking. These might deliver valuable information on whether the described scenarios may be applicable to humans.

\section{Irradiation Influences Homing and Engraftment of MSCs}

Devine et al. [32] reported that one of their baboons which had received no irradiation showed less engraftment of MSCs. After severe multi-organ injury in primates post 8 Gy irradiation, MSCs engrafted in the irradiated group in muscle, skin, bone marrow, and gut, as assessed via PCR up to 82 days postinfusion [33]. Irradiation was also used to induce local accumulation of MSCs. In a murine breast cancer model, Klopp et al. [34] have recently demonstrated a superior engraftment of mMSCs to tumors which had received prior irradiation $48 \mathrm{~h}$ post transplantation.

\section{Role of Inflammation}

It is likely that inflammation is a major cue to direct migration of transplanted MSCs. As shown by Kraitchman et al. [30], myocardial infarction rim zones were the areas where MSCs accumulate, as demonstrated with iron particle labeling of MSCs in tissue sections. This fits in well with the 24-96 $\mathrm{h}$ post-myocardial infarction time window when general leukocyte immigration occurs [29]. Penna et al. [35] have recently worked with MSCs in a rat myocardial infarction model, and after local injection showed that MSCs migrate well in non-infarcted hearts, however, that in the infarcted hearts' border zones, MSCs remained in place rather than migrating away and showed different morphology with some cells starting to express a myocyte marker and connexin-43 at the border to myocytes. All changes were observed within $6 \mathrm{~h}$ of transplantation of MSCs. Similar observations were made in an acute tubular kidney injury model. Hererra et al. [36] saw in a murine model that the CD44 molecule was clearly required for immigration of the mMSCs into the damaged tissue. Similarly, the group of Lange et al. [37] demonstrated the ability of MSCs applied via the arterial route into acutely damaged kidneys to provide significant repair function, again early after transplant. In a brain model, MSCs have been shown to incorporate into ischemic areas where they can deliver brain-derived neurotrophic factor (BDNF), intended to provide growth signals for neural re- 
Table 2. Assays which are available and could be used to correlate or predict migration, adhesion, and homing capacity in transplanted GMP MSC populations

\begin{tabular}{|c|c|c|c|}
\hline Assay & Approximate time & Function measured & Receptors \\
\hline \multicolumn{4}{|l|}{ Flow cytometry } \\
\hline Receptor surface expression & $2 \mathrm{~h}$ & none, but expression is prerequisite & $\begin{array}{l}\text { expression of chemokine receptors may be } \\
\text { altered in short time intervals e.g. during }\end{array}$ \\
\hline $\begin{array}{l}\text { Binding of MSCs to } \\
\text { bead-coated substrates }\end{array}$ & $2 \mathrm{~h}$ & $\begin{array}{l}\text { binding of MSCs to ligands under } \\
\text { shear stress }\end{array}$ & $\begin{array}{l}\text { GMP preparation or during pre-stimulation } \\
\text { function test for many receptors, mainly } \\
\text { integrins and chemokines }\end{array}$ \\
\hline Polarization on plastic layer & $2 \mathrm{~h}$ & response to integrins plus chemokines & chemokine receptors \\
\hline Transwell migration & $\begin{array}{l}8 \mathrm{~h} \text { to over night } \\
\text { (but relatively little } \\
\text { operating time required) }\end{array}$ & response to chemokines & $\begin{array}{l}\text { chemokine receptors; candidates are } \\
\text { e.g. SDF-1/CXCR4, fractalkine/CX3CR1, } \\
\text { IL-8/CXCR } 1 \text { and } 2\end{array}$ \\
\hline $\begin{array}{l}\text { Flow chamber adhesion to } \\
\text { isolated endothelial ligands }\end{array}$ & $\begin{array}{l}3-4 \mathrm{~h} \text { (operating time } \\
\text { is close to running } \\
\text { time for approximately } \\
6 \text { measuring points) }\end{array}$ & $\begin{array}{l}\text { adhesion via integrins and its } \\
\text { strengthening by chemokines; } \\
\text { in cases of selectins, also rolling }\end{array}$ & $\begin{array}{l}\text { most receptors can be investigated and } \\
\text { function quantified }\end{array}$ \\
\hline $\begin{array}{l}\text { Short term homing in } \\
\text { NOD/SCID mice }\end{array}$ & $\begin{array}{l}12-24 \text { h plus workup; } \\
\text { few experimental points } \\
\text { possible }\end{array}$ & $\begin{array}{l}\text { homing to sites of injury; might be } \\
\text { highly predictable since MSC } \\
\text { effects so far seem to be early }\end{array}$ & integrated entire homing response \\
\hline Animal experiment & several days to longer & depending on endpoints used & $\begin{array}{l}\text { integrated entire response; homing can be } \\
\text { included }\end{array}$ \\
\hline
\end{tabular}

generation [38]. This also argues for the ability of transplanted MSCs to reach damaged tissues, even in the absence of leukocyte-rich inflammation as in the central nervous system. Taken together, MSCs seem to display a tropism for inflammatory tissue, and are likely to act very early after transplantation.

\section{Evidence for Mesenchymal Stem Cells Homing from Studies in Patients}

\section{Bone Marrow and Hematopoietic System}

There are now at least 5 studies looking at the engraftment of transplanted hMSCs in bone marrow, or interaction with hematopoietic regenerative function. Koc et al. [23] have coinfused tumor patients with hematopoietic stem cells and culture-expanded MSCs. Horwitz et al. [24, 25] have shown that MSCs can be successfully used in children to correct the gene defect of osteogenesis imperfecta, a very severe disease starting in small children. Both investigators could demonstrate that transfused MSCs efficiently home to bone marrov or sites of bone formation. Lazarus et al. [39] have used MSCs in conjunction with hematopoietic stem cell transplants to increase engraftment. Also, engraftment of the MSCs could be demonstrated. Le Blanc et al. [40] and Ball et al. [41] examined the ability of MSCs to enhance engraftment of allogeneic MSCs, suggesting that transplanted MSCs may have a regulatory role in the bone marrow microenvironment.

\section{Graft versus Host Disease}

In patients after allogeneic transplantation, striking data have come from the European Group for Blood and Marrow Transplantation (EBMT), indicating that transplantation of MSCs from stem cell donors or from third party donors is beneficial in otherwise untreatable graft versus host disease (GvHD). This has, preferentially in patients with gastrointestinal GvHD, led to significant success [42-44]. In children, Müller et al. [45] have recently demonstrated similar findings. So far, it is not known where the transplanted MSCs localize to. However, there are two tempting similarities to the preclinical requirements of MSC functions: Effects have been observed early after transplant, and the responding patients show severe inflammation.

Two studies from an Iranian group have recently been published, one in the context of myocardial infarction, and the other in patients with liver cirrhosis. Mohyeddin-Bonab et al. [46] looked at the results of MSC transplantation in patients undergoing coronary artery bypass grafting post myocardial infarction, and found functional improvement as measured by increases in left ventricular ejection fraction. Mohamadnejad et al. [47] reported on 4 patients receiving MSCs i.v. by the portal vein route, showing that MSC transplantation of approximately $30 \times 10^{6}$ MSCs seems feasible and safe in the treatment of decompensated liver cirrhosis. These are early results; further confirmation by other investigators or follow-up patients is warranted, and determination of homing of MSCs has not been an endpoint of the protocols. 


\section{Assays to Track Migration, Adhesion, and Potentially Homing Quality of GMP Preparations of MSCs}

In 2001, Voermans et al. [48] showed that the outcome of hematopoietic transplant recovery speed correlates highly with in vitro migratory capacity through endothelial cells. They employed a transwell model which they validated to be dependent on integrins, chemokines, and other molecules such as CD31. Thus, engraftment time could be predicted using a relatively simple migration assay, dependent on the function of classical homing receptors. It is tempting to speculate that a similar in vitro/in vivo functional relationship may exist for MSC transplantation, homing, and engraftment as well. However, such data do not yet exist. Table 2 proposes several assay systems which might be investigated in order to correlate or predict homing functions, and thus possibly correlate them with function of MSCs as cellular therapeutics. Moreover, it seems reasonable to postulate that GMP preparations of MSCs, before clinically used, would be quality-controlled in some way as to their migratory properties. Especially their chemokine receptor repertoire can, from the preclinical data, be assumed to predict their ability to use some homing pathways. Moreover, the example of CD44 which can be rendered a functional E-selectin ligand in MSCs, underscores the potential value of a more intense documentation of migratory capabilities of MSCs used in studies. However, care should be taken, since a relevance of the named homing receptors has in no cases been established yet, and several preparations looking differently with respect to homing receptor expression and function might well be suitable for effective cellular therapy in patients in need of MSCs.

\section{References}

1 Luster AD, Alon R, von Andrian UH: Immune cell migration in inflammation: present and future therapeutic targets. Nat Immunol 2005;6:1182-1190.

2 Broxmeyer HE: Chemokines in hematopoiesis. Curr Opin Hematol 2008;15:49-58.

$\checkmark 3$ Butcher EC: Leukocyte-endothelial cell recognition: three (or more) steps to specificity and diversity. Cell 1991;67:1033-1036.

4 Springer T: Traffic signals for lymphocyte recirculation and leucocyte emigration: the multistep paradigm. Cell 1994;76:301-314.

5 Ley K: Arrest chemokines. Microcirculation 2003; 10:289-295.

6 Alon R, Feigelson S: From rolling to arrest on blood vessels: leukocyte tap dancing on endothelial integrin ligands and chemokines at sub-second contacts. Seminars Immunol 2002;14:93-104.

7 Alon R, Dustin ML: Force as a facilitator of integrin conformational changes during leukocyte arrest on blood vessels and antigen-presenting cells. Immunity 2007;26:17-27.

$>8$ Vestweber D: Adhesion and signaling molecules controlling the transmigration of leukocytes through endothelium. Immunol Rev 2007;218: 178-196.

9 Wagner DD, Frenette PS: The vessel wall and its interactions. Blood 2008;111:5271-5281.

10 Sipkins DA, Wei X, Wu JW, Runnels JM, CoteD, Means TK, Luster AD, Scadden DT, Lin CP: In vivo imaging of specialized bone marrow endothelial microdomains for tumour engraftment. Nature 2005;435:969-973.

-11 Ruster B, Gottig S, Ludwig RJ, Bistrian R, Muller S, Seifried E, Gille J, Henschler R: Mesenchymal stem cells (MSCs) display coordinated rolling and adhesion behavior on endothelial cells. Blood 2006;108: 3938-3944.

12 Sackstein R, Merzaban JS, Cain DW, Dagia NM, Spencer JA, Lin CP, Wohlgemuth R: Ex vivo glycan engineering of CD44 programs human multipotent mesenchymal stromal cell rafficking to bone. Nat Med 2008;14:181-187.

13 Bruder SP, Jaiswal N, Ricalton NS, Mosca JD, Kraus $\mathrm{KH}$, Kadiyala S: Mesenchymal stem cells in osteobiology and applied bone regeneration. Clin Orthop Relat Res 1998;(355 suppl):S247-256
14 Majumdar MK, Keane-Moore M, Buyaner D, Hardy WB, Moorman MA, McIntosh KR, Mosca JD: Characterization and functionality of cell surface molecules on human mesenchymal stem cells. J Biomed Sci 2003;10:228-241.

15 Segers VF, van Riet I, Andries LJ, Lemmens K, Demolder MJ, De Becker AJ, Kockx MM, De Keulenaer GW: Mesenchymal stem cell adhesion to cardiac microvascular endothelium: activators and mechanisms. Am J Physiol Heart Circ Physiol 2006; 290:H1370-1377.

16 Honczarenko M, Le Y, Swierkowski M, Ghiran I, Glodek AM, Silberstein LE: Human bone marrow stromal cells express a distinct set of biologically functional chemokine receptors. Stem Cells 2006; 24:1030-1041.

17 Sordi V, Malosio ML, Marchesi F, Mercalli A, Melzi R, Giordano T, Belmonte N, Ferrari G, Leone BE, Bertuzzi F, Zerbini G, Allavena P, Bonifacio E, Piemonti L: Bone marrow mesenchymal stem cells express a restricted set of functionally active chemokine receptors capable of promoting migration to pancreatic islets. Blood 2005;106:419-427.

18 Wynn RF, Hart CA, Corradi-Perini C, O’Neill L, Evans CA, Wraith JE, Fairbairn LJ, Bellantuono I: A small proportion of mesenchymal stem cells strongly expresses functionally active CXCR4 receptor capable of promoting migration to bone marrow. Blood 2004;104:2643-2645.

19 Shi M, Li J, Liao L, Chen B, Li B, Chen L, Jia H, Zhao RC: Regulation of CXCR4 expression in human mesenchymal stem cells by cytokine treatment: role in homing efficiency in NOD/SCID mice. Haematologica 2007;92:897-904.

20 Ji JF, He BP, Dheen ST, Tay SS: Interactions of chemokines and chemokine receptors mediate the migration of mesenchymal stem cells to the impaired site in the brain after hypoglossal nerve injury. Stem Cells 2004;22:415-427.

21 Wang L, Li Y, Chen X, Chen J, Gautam SC, Xu Y, Chopp M: MCP-1, MIP-1, IL-8 and ischemic cerebral tissue enhance human bone marrow stromal cell migration in interface culture. Hematology 2002;7:113-117.
22 De Becker A, Van Hummelen P, Bakkus M, Vande Broek I, De Wever J, De Waele M, Van Riet I: Migration of culture-expanded human mesenchymal stem cells through bone marrow endothelium is regulated by matrix metalloproteinase- 2 and tissue inhibitor of metalloproteinase-3. Haematologica 2007;92:440-449.

23 Koc ON, Gerson SL, Cooper BW: Rapid hematopoietic recovery after coinfsion of autologousblood stem cells and culture-expanded marrow mesenchymal stem cells in advanced breast cancer patients receiving high-dose chemotherapy. J Clin Oncol 2000;18:307-316.

24 Horwitz EM, Prockop DJ, Fitzpatrick LA: Transplantability and therapeutic effects of bone-marrow derived mesenchymal cells in children with osteogenesis imperfecta. Nat Med 1999;5:309-313.

25 Horwitz EM, Gordon PL, Koo WK, Marx JC, Neel MD, McNall RY, Muul L, Hofmann T: Isolated allogeneic bone marrow-derived mesenchymal cells engraft and stimulate growth in children with osteogenesis imperfecta: implications for cell therapy of bone. Proc Natl Acad Sci U S A 2002;99: 8932-8937.

26 Gao J, Dennis JE, Muzic RF, Lundberg M, Caplan AI: The dynamic in vivo distribution of bone marrow-derived mesenchymal stem cells after infusion. Cells Tissues Organs 2001;169:12-20.

27 Lorenz MR, Holzapfel V, Musyanovych A, Nothelfer K, Walther P, Frank H, Landfester K, Schrezenmeier H, Mailänder V: Uptake of functionalized, fluorescent-labeled polymeric particles in different cell lines and stem cells. Biomaterials 2006;27:2820-2828.

28 Frank JA, Miller BR, Arbab AS, Zywicke HA, Jordan EK, Lewis BK, Bryant LH Jr, Bulte JWM: Clinically applicable labeling of mammalian and stem cells by combining superparamagnetic iron oxides and transfection agents. Radiology 2003;228: 480-487.

29 Thakur ML, Gottschalk A, Zaret BL: Imaging experimental myocardial infarction with indium-111labeled autologous leukocytes: effects of infarct age and residual regional myocardial blood flow. Circulation 1979;60:297-305. 
30 Kraitchman DL, Tatsumi M, Gilson WD, Ishimori T, Kedziorek D, Walczak P, Segars WP, Chen HH, Fritzges D, Izbudak I, Young RG, Marcelino M, Pittenger MF, Solaiyappan M, Boston RC, Tsui BMW, Wahl RL, Bulte JWM: Dynamic imaging of allogeneic mesenchymal stem cells trafficking to myocardial infarction. Circulation 2005;112:14511461.

31 Anjos-Afonso F, Siapati EK, Bonnet D: In vivo contribution of murine mesenchymal stem cells into multiple cell-types under minimal damage conditions. J Cell Sci 2004;117:5655-5664.

-32 Devine SM, Cobbs C, Jennings M, Bartholomew A, Hoffman R: Mesenchymal stem cells distribute to a wide range of tissues following systemic infusion into nonhuman primates. Blood 2003;101:29993001.

-33 Chapel A, Bertho JM, Bensidhoum M, Fouillard L, Young RG, Frick J, Demarquay C, Cuvelier F, Mathieu E, Trompier F, Dudoignon N, Germain C, Mazurier C, Aigueperse J, Borneman J, Gorin NC, Gourmelon P, Thierry D: Mesenchymal stem cells home to injured tissues when co-infused with hematopoietic cells to treat a radiation-induced multi-organ failure syndrome. J Gene Med 2003;5: 1028-1038.

\34 Klopp AH, Spaeth EL, Dembinski JL, Woodward WA, Munshi A, Meyn RE, Cox JD, Andreeff M, Marini FC: Tumor irradiation increases the recruitment of circulating mesenchymal stem cells into the tumor microenvironment. Cancer Res 2007;67: 11687-11695.

-35 Penna C, Raimondo S, Ronchi G, Rastaldo R, Mancardi D, Cappello S, Losano G, Geuna S, Pagliaro P: Early homing of adult mesenchymal stem cells in normal and infarcted isolated beating hearts. J Cell Mol Med 2008;12:507-521.
36 Herrera MB., Bussolati B, Bruno S, Morando L, Mauriello-Romanazzi G, Sanavio F, Stamenkovic I, Biancone L, Camussi G: Exogenous mesenchymal stem cells localize to the kidney by means of CD44 following acute tubular injury. Kidney Int 2007;72: 430-441.

37 Togel F, Hu Z, Weiss K, Isaac J, Lange C, Westenfelder C: Administered mesenchymal stem cells protect against ischemic acute renal failure through differentiation-independent mechanisms. Am J Physiol Renal Physiol 2005;289:F31-F42.

38 Kurozumi K, Nakamura K, Tamiya T, Kawano Y, Kobune M, Hirai S, Uchida H, Sasaki K, Ito Y, Kato K, Honmou O, Houkin K, Date I, Hamada H: BDNF gene-modified mesenchymal stem cells promote functional recovery and reduce infarct size in the rat middle cerebral artery occlusion model. Mol Ther 2004;9:189-197.

39 Lazarus HM, Koc ON, Devine SM, et al: Cotransplantation of HLA-identical sibling cultureexpanded mesenchymal stem cells and hematopoietic stem cells in hematologic malignancy patients. Biol Blood Marrow Transplant 2005;11:389-398.

40 Le Blanc K, Samuelsson H, Gustafsson B, et al: Transplantation of mesenchymal stem cells to enhance engraftment of hematopoietic stem cells. Leukemia 2007;21:1733-1738.

41 Ball LM, Bernardo ME, Roelofs H, et al: Cotransplantation of ex vivo expanded mesenchymal stem cells accelerates lymphocyte recovery and may reduce the risk of graft failure in haploidentical hematopoietic stem-cell transplantation. Blood 2007;110:2764-2767.

42 Le Blanc K, Rasmusson I, Sundberg B, Götherström C, Hassan M, Uzunel M, Ringdén O: Treatment of severe acute graft-versus-host disease with third party haploidentical mesenchymal stem cells. Lancet 2004;363:1439-1441.

43 Ringden O, Uzunel M, et al: Mesenchymal stem cells for treatment of therapy-resistant graft-versus-host disease. Transplantation 2006;81:1390.
44 Le Blanc K, Frassoni F, Ball L, Locatelli F, Roelofs H, Lewis I, Lanino E, Sundberg B, Bernardo ME, Remberger M, Dini G, Egeler RM, Bacigalupo A, Fibbe W, Ringdén O: Mesenchymal stem cells for treatment of steroid-resistant, severe, acute graftversus-host disease: a phase II study. Lancet 2008 371:1579-1586

45 Müller I, Kordovich S, Holzwarth C, Isensee G, Lang P, Neunhoeffer F, Dominici M, Greil J, Handgretinger R: Application of multipotent mesenchymal stromal cells in pediatric patients following allogeneic stem cell transplantation. Blood Cells Mol Dis 2008;40:25-32.

46 Mohyeddin-Bonab M, Mohamad-Hassani M, Alimoghaddam K, Sanatkar M, Gasemi M, Mirkhan H, Radmehr H, Salehi M, Eslami M, Farhig-Parsa A, Emami-Razavi H, Alemohammad MG, Solimani AA, Ghavamzadeh A, Nikbin B: Autologous in vitro expanded mesenchymal stem cell therapy for human old myocardial infarction. Arch Iran Med 2007;10:467-473.

47 Mohamadnejad M, Alimoghaddam K, MohyeddinBonab M, Bagheri M, Bashtar M, Ghanaati H, Baharvand $\mathrm{H}$, Ghavamzadeh A, Malekzadeh R: Phase 1 trial of autologous bone marrow mesenchymal stem cell transplantation in patients with decompensated liver cirrhosis. Arch Iran Med 2007;10: 459-466.

48 Voermans C, Kooi M, Rodenhuis S, et al: In vitro migratory capacity of CD34+cells is related to hematopoietic recovery after autologous stem cell transplantation. Blood 2001;97:799-804.

49 Herrera MB, Bussolati B, Bruno S, Fonsato V, Romanazzi GM, Camussi G: Mesenchymal stem cells contribute to the renal repair of acute tubular epithelial injury. Int J Mol Med 2004;14:1035-1041.

50 Hung SC, Pochampally RR, Hsu SC, Sanchez C, Chen SC, Spees J, Prockop DJ: Short-term exposure of multipotent stromal cells to low oxygen increases their expression of CX3CR1 and CXCR4 and their engraftment in vivo. Plos ONE 2007;2: e416. 